\title{
Foliar Symptom Expression of Wood Decay in Actinidia deliciosa in Relation to Environmental Factors
}

\author{
Stefano Di Marco and Fabio Osti, Istituto di Biometeorologia, Consiglio Nazionale delle Ricerche, Via P. Gobetti, \\ 101, 40129 Bologna, Italy
}

\begin{abstract}
Di Marco, S., and Osti, F. 2008. Foliar symptom expression of wood decay in Actinidia deliciosa in relation to environmental factors. Plant Dis. 92:1150-1157.

Kiwifruit vines (Actinidia deliciosa var. deliciosa) have recently been affected by a new form of decay caused by several fungi that produce different types of wood deterioration in the trunk and cordons. Surveys were conducted over a period of 5 years to investigate epidemiological aspects of the disease in a typical Italian growing area (Emilia-Romagna), where kiwifruit is widely cultivated and where the disease was noted for the first time. The disease was widespread over the kiwifruit growing area surveyed, and its incidence increased over the course of the survey. No relationship was found between vineyard soil characteristics or management methods and the annual incidence of symptomatic vines. Foliar symptoms did not consistently express every season even on obviously infected vines. The time of appearance and the development of the disease were correlated with plant phenology and temperature. In particular, from June to $\mathrm{Au}-$ gust, temperature seemed to affect the annual incidence of the disease in terms of both symptomatic shoots and symptomatic vines. The aspects in common between the decay of kiwifruit and esca of grapevine could be hypothesized and are discussed.
\end{abstract}

Kiwifruit (Actinidia deliciosa var. deliciosa) is an important crop in Italy, New Zealand, Chile, France, Greece, the United States, Spain, and to a lesser extent, Portugal. More than $70 \%$ of the kiwifruit world crop is cultivated in Italy and New Zealand. Production has generally increased in 2003 to 2005: in 2005, Italy produced 426,309 metric tons of kiwifruit (22), while in New Zealand the harvest reached 329,000 metric tons (33). According to the United Nations Food and Agriculture Organization (FAO), global production of kiwifruit over the last decade has ranged between 870,000 and 1 million metric tons per annum (21).

Kiwifruit production is sensitive to weather conditions, such as winter chilling, growing season thermal time, and annual rainfall (35), as well as cultural practices such as pruning, pollination, fertilization, and water supply (5). Seasonal yield losses caused by different fungal pathogens infecting kiwifruit can usually be reduced by a limited use of fungicides.

Among the most common fungal pathogens, Botrytis, Phytophthora, Armillaria, Rosellinia, Rhizoctonia, Sclerotinia, and Verticillium species have been associated with pathogenic deterioration of the roots

Corresponding author: Stefano Di Marco

E-mail: s.dimarco@ibimet.cnr.it

Accepted for publication 15 April 2008.

doi:10.1094/PDIS-92-8-1150

(C) 2008 The American Phytopathological Society and stem (2). In 1999, a wood decay of kiwifruit vines was noted for the first time in some 9- to 10-year-old cv. Hayward Emilia-Romagna vineyards (4). By 2000, the incidence of vines with foliar disease symptoms increased in all Italian kiwi vineyards $(12,13)$. Elena and Paplomatas (15) reported the occurrence of a similar disease in Greece and the involvement of the basidiomycete Fomitiporia punctata (Fr.) Murrill (now classed as Fomitiporia mediterranea M. Fish.) in causing wood decay. Soon after the first report on the wood decay of kiwifruit, there was an upsurge of reports of new diseases affecting the wood of kiwifruit plantations of cv. Hayward. Diseases were described under the names of "Esca-like" in France $(19,20)$ and "Elephantiasis" in Italy $(31,32,34)$. Finally, a wood disease of kiwifruit was also reported in New Zealand (24).

The wood decay of kiwifruit is associated with symptoms on the foliage that appear in early summer, about 1 month after bloom. Leaf symptoms begin as small, pale green spots irregularly distributed on the upper side of the leaf. The spots enlarge, developing into a series of irregularly shaped chlorotic areas that soon become necrotic with a distinct margin. Eventually, the leaf surface will be covered by the spots, and the affected leaves curl, wilt, and drop prematurely. These symptoms occur on the current season's shoots, which develop from canes growing horizontally along the trellis wire. Fruit are stunted and may not reach full maturity, depending on the time of appearance of foliar symptoms on shoots.
Trunk and cordons of symptomatic vines revealed two types of wood deterioration: a decay distinguished by a bleached appearance usually affecting a large area of the wood section, and a brown discoloration which often appeared as streaks in longitudinal section. Normally, discolorations surround and precede the decay $(9,12)$. Fungal isolations from wood showing decay yielded the basidiomycete $F$. mediterranea M. Fish., whereas Phaeoacremonium aleophilum W. Gams, Crous, M.J. Wingf. \& Mugnai, Phaeoacremonium parasiticum (Ajello, Georg \& C.J.K. Wang) W. Gams, Crous \& M.J. Wingf., and Cadophora malorum (Kidd \& Beaumont) W. Gams were isolated from discolored wood $(8,9)$. At least two of the above fungi ( $F$. mediterranea and $P$. aleophilum) are also involved in esca disease of grapevine $(17,29)$. Pathogenicity tests on potted kiwifruit vines cv. Hayward with $F$. mediterranea, $P$. aleophilum, $P$. parasiticum, and C. malorum provided clear evidence of the ability of all fungal species to colonize wood and reproduce the different types of deterioration (9).

This paper reports surveys conducted to investigate some epidemiological aspects of the disease in typical Emilia-Romagna growing areas, where kiwifruit is widely cultivated and the disease was noted for the first time. Different field studies were conducted: the spread of the disease and vineyard characteristics were correlated; the timing of first symptoms' appearance and the disease development over seasons and in the vineyard were recorded; and the correlation between the disease and phenology or climatic factors was assessed. The relationship between wood decay of kiwifruit and esca of grapevine is also discussed.

\section{MATERIALS AND METHODS}

Areas surveyed and procedure followed in the survey. Field surveys to assess the incidence of wood decay of kiwifruit were conducted on kiwifruit Actinidia deliciosa var. deliciosa cv. Hayward vineyards. The surveys were carried out in a typical kiwifruit growing area of over 2,500 ha located in Emilia-Romagna, a north-central region of Italy.

The disease was identified by visual inspection assessing the presence of foliar symptoms for each vine (Fig. 1). Vines that showed at least two symptomatic leaves were considered to be infected by wood 
decay. The annual incidence of the disease was assessed from the last 10 days of $\mathrm{Au}$ gust to the first week of September, this period corresponding to the maximum of foliar symptom expression.

Spread of the disease and vineyard characteristics in the surveyed area. Surveys were performed in 89 vineyards. For each vineyard, a plot of about 100 vines was chosen in late winter during the dormant season in 2003. At the end of August of the same year, all vines of each plot in each vineyard were inspected and classified as symptomatic or apparently healthy. For each vineyard, incidence of the disease was simply expressed as percentage of symptomatic plants over all vines of the plot.

For each vineyard, the following parameters were recorded: age of the vineyard, percentage of pollinators (nonbearing male plants), training system (types), management of irrigation, and fertilization (nitrogen, phosphorus, potassium, and iron). Soil characteristics were also determined using analytical methods described in official Italian procedures (27): in particular, Bouyoucos hydrometer for texture, potentiometric for $\mathrm{pH}$, Walkley and Black for organic substance, Drouineau for active lime, Kjeldahl for total nitrogen, Olsen for available phosphorus, and Ammonium acetate for exchangeable potassium.

Timing of first symptom appearance and consequent disease development in lowland vineyards over four seasons. The spread of the disease was assessed annually over four consecutive growing seasons (2003 to 2006) in four vineyards located in a lowland area, 8 to 11 years old, in which the disease appeared for the first time in 2003. Vineyards were located in an area characterized by similar temperatures and rainfall. For each vineyard, 205 to 237 vines were visually inspected for symptomatic leaves.

Each year, two types of diseased vines were considered: (i) vines that showed foliar symptoms in that year of survey, designated "manifest diseased vine"; and (ii) after the first year of inspection, vines that showed foliar symptoms in at least one previous year, but not in that year of survey, designated "asymptomatic diseased vine". Thus, a map was developed for each year that depicted the status of the vines surveyed in each vineyard. For each year, data were expressed as: annual disease incidence calculated as the number of manifest diseased vines over the number of all inspected vines multiplied by 100 ; and cumulative disease incidence calculated as the number of manifest plus asymptomatic diseased vines over the number of all inspected vines multiplied by 100 . Each year, results were expressed as mean percentage of annual and cumulated incidence calculated for the four vineyards.

Timing of first symptom appearance and consequent disease development on vines within a single vineyard surveyed over four seasons. Time of appearance and the spread of disease in the vineyard during the growing season was studied for four consecutive years (2002 to 2005) on 57 fruiting vines in a hilly vineyard planted in 1985.

Weekly inspections were conducted during the growing season in order to assess: time of bloom, appearance of first disease symptoms on leaves, and spread of symptoms on each vine of the vineyard. The number of symptomatic shoots on each symptomatic vine was assessed each 15 days. Time of inspection was expressed as days after full blooming (DAFB).

For each inspection, the ratio of symptomatic vines was calculated as the number of vines showing foliar disease symptoms on at least one symptomatic shoot, over the number of all inspected vines, and multiplying by 100 . The ratio of symptomatic shoots was calculated as number of symptomatic shoots showing at least two symptomatic leaves over the total amount of fruiting shoots per vine, and multiplying by 100 . The results were expressed as mean percentage of symptomatic shoots or vines for the 2002 to 2005 period.

Temperature, rainfall, and irrigation records. Temperature and rainfall data were recorded daily from weather stations at Forlì airport and from the National Agro-Meteorological Data Bank of the Central Office of Agro-Ecology (UCEA). Weather recording instruments were located about 10 to $15 \mathrm{~km}$ away in a straight line from the four vineyards. In the case of the hilly vineyard, rainfall and temperature data were recorded by weather recording equipment of ARPA (Regional Agency for Environmental Prevention in EmiliaRomagna) located about $5 \mathrm{~km}$ in a straight line from the vineyard.

For each month, temperature and rainfall data were expressed as daily average temperature $\left({ }^{\circ} \mathrm{C}\right)$ and monthly total amount of rainfall $(\mathrm{mm})$, respectively. In the case of the hilly vineyard, temperatures were related to DAFB.

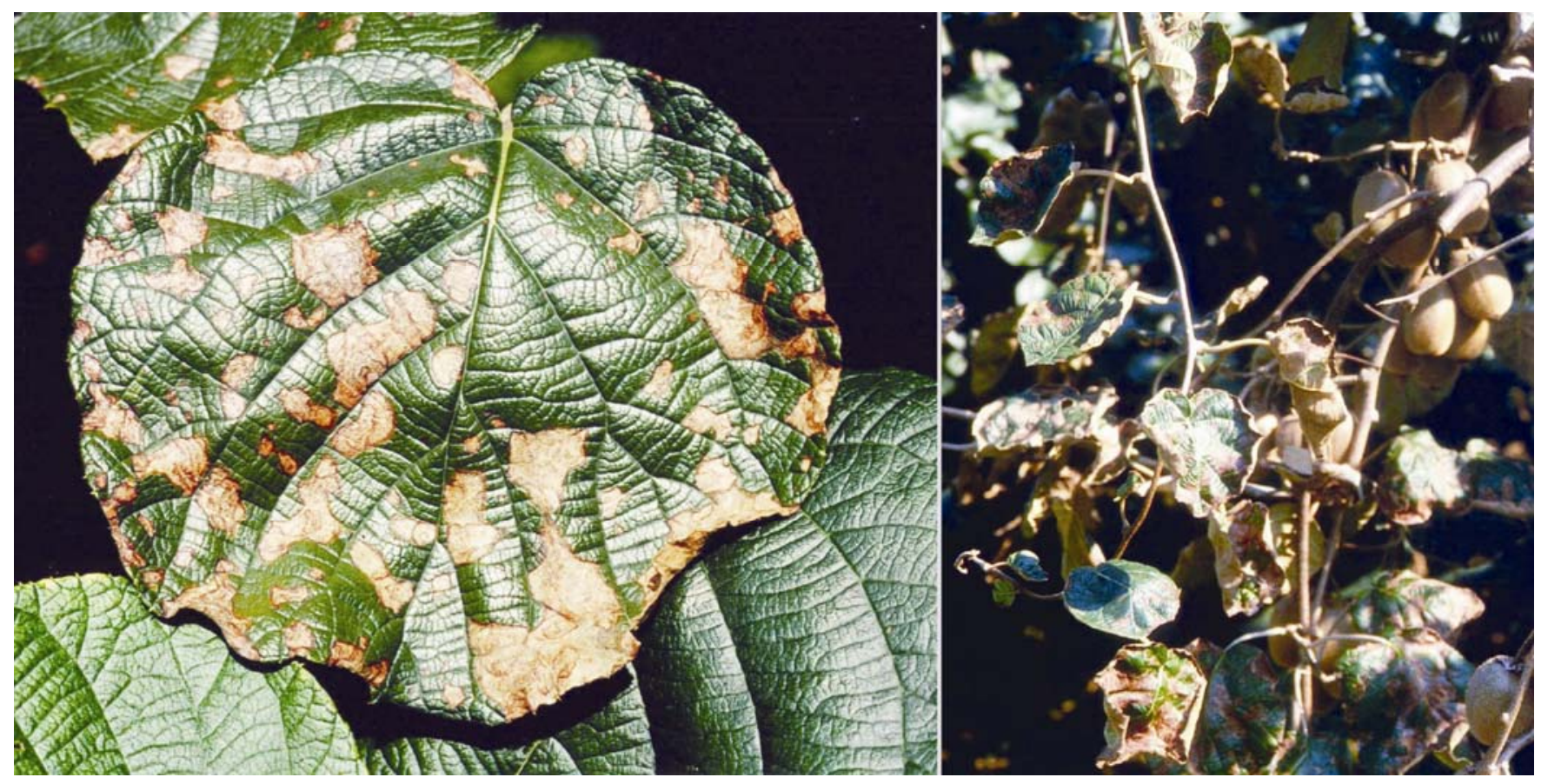

Fig. 1. Foliar symptoms of wood decay of kiwifruit first appear as chlorotic spots on the upper surface of the leaf, which expand and become necrotic, developing into irregular-shaped areas that eventually cover most of the leaf surface (left). When disease is severe, the affected leaves curl, wilt, and fall prematurely (right). 
Table 1. Relationship between disease incidence assessed in 2003 and vineyard, soil, and nutrition parameters

\begin{tabular}{|c|c|c|c|c|c|c|}
\hline Parametersw & $\begin{array}{c}\text { Measurement } \\
\text { unit }\end{array}$ & $\begin{array}{c}\text { Mean value } \\
\text { of the parameter }\end{array}$ & $\begin{array}{l}\text { Standard } \\
\text { deviation }\end{array}$ & $R^{2}$ & $\begin{array}{l}\text { Statistical } \\
\text { analysis }^{x}\end{array}$ & Vineyards $^{\mathbf{y}}$ \\
\hline Age & Years & 16.6 & 2.91 & $0.0177^{z}$ & NS & 71 \\
\hline Pollinators & $\%$ & 13.1 & 3.28 & 0.0008 & NS & 77 \\
\hline Acidity/alkalinity degree & $\mathrm{pH}$ & 7.8 & 0.35 & 0.0028 & NS & 89 \\
\hline Active lime & $\%$ & 4.2 & 2.73 & 0.0074 & NS & 76 \\
\hline Organic substance & $\%$ & 1.7 & 0.48 & 0.0105 & NS & 89 \\
\hline Total nitrogen $(\mathrm{N})$ & $\%$ & 1.1 & 0.47 & 0.0021 & NS & 89 \\
\hline Available phosphorus $\left(\mathrm{P}_{2} \mathrm{O}_{5}\right)$ & $\mathrm{mg} \mathrm{kg}^{-1}$ & 58.1 & 50.05 & 0.0082 & NS & 84 \\
\hline Exchangeable potassium $\left(\mathrm{KO}_{2}\right)$ & $\mathrm{mg} \mathrm{kg}^{-1}$ & 270.1 & 106.09 & 0.0012 & NS & 83 \\
\hline Sand & $\%$ & 29.9 & 12.03 & 0.0122 & NS & 89 \\
\hline Silt & $\%$ & 45.5 & 8.39 & 0.0311 & NS & 89 \\
\hline Clay & $\%$ & 24.6 & 7.45 & 0.0004 & NS & 89 \\
\hline $\mathrm{N}$ & $\mathrm{kg} \mathrm{ha}^{-1}$ & 111.2 & 37.36 & 0.0064 & NS & 77 \\
\hline $\mathrm{P}$ & $\mathrm{kg} \mathrm{ha}^{-1}$ & 26.9 & 12.37 & 0.0071 & NS & 29 \\
\hline K & $\mathrm{kg} \mathrm{ha}^{-1}$ & 75.6 & 26.79 & 0.0805 & NS & 67 \\
\hline $\mathrm{Fe}$ & $\mathrm{kg} \mathrm{ha}^{-1}$ & 13.2 & 9.86 & 0.1873 & $*$ & 52 \\
\hline
\end{tabular}

${ }^{\mathrm{w}}$ Parameters were obtained from the vineyard (age and percentage of pollinators) soil (pH, active lime, total nitrogen, available phosphorus, exchangeable potassium, and texture) and fertilization management (nitrogen, phosphorus, potassium, and iron).

$\mathrm{x} *=$ significant differences at $\alpha=0.05$. NS = nonsignificant.

y Number of vineyards considered for each given parameter.

${ }^{\mathrm{z}}$ The correlation coefficient $\left(R^{2}\right)$ was calculated with the least square method.

All plantations of kiwifruit surveyed were drip-irrigated during June to August, with the amount of water supplied dependent on rainfall. The total amount of irrigation water per vineyard $(\mathrm{mm})$ was calculated monthly, considering the total time of irrigation (h), the drip flow rate (liters $/ \mathrm{m}^{2}$ min), and the vineyard area. For each month, total amount of rainfall was added to irrigation water and expressed as total amount of water $(\mathrm{mm})$ for each vineyard.

Statistical analysis. Spread of the disease and vineyard characteristics in the surveyed area. The relationship between each parameter and the incidence of disease was determined by linear regression $\left(R^{2}\right)$ and tested for significance at the 0.05 level. In addition, vineyards in which all parameters were recorded, except phosphorus fertigation (recorded in less than $33 \%$ of surveyed vineyards), were subjected to hierarchical cluster analysis (average linkage method). Groups of vineyards generated by cluster analysis were compared with the disease incidence in order to show possible correlations. The statistical analysis was performed using the SAS system software version 9.1 (SAS Institute, Cary, NC, USA).

Surveys of the first appearance in vineyards and spread of the disease. The annual and cumulated incidence of each of the four vineyards were subjected to statistical analysis using Duncan's multiple range test $(\alpha=0.05)$ to determine which means were significantly different (version 9.1, SAS Institute).

Correlation between temperature and annual disease incidence. For each year of the survey, the rate of correlation between the mean of annual disease incidence of the four vineyards and monthly average daily temperature was statistically determined by nonlinear regression analysis using SigmaPlot 9.0 software (Systat Software Inc., CA, USA). The annual inci- dence assessed each year was modeled as a function of daily average temperature of June, July, and August by fitting curves to the measured data. The following functions were used for June:

$$
y=\frac{A x}{B+x}
$$

and for July and August:

$$
y=\frac{a}{1+\left(\frac{x-x_{0}}{b}\right)^{2}}
$$

where $y$ is the annual incidence, $x$ is the monthly average daily temperature, $A$ and $B$ parameterize the horizontal and vertical asymptote, respectively, $a$ is the peak point of the curve, $b$ is the full width of the curve at one-half of the peak value, and $x_{0}$ parameterizes the temperature of the peak point of the curve.

Results were represented by regression curves of mean annual disease incidence on graphics drawn by taking temperature or water on the abscissa and incidence on the ordinate at $P<0.0001$.

\section{RESULTS}

Spread of the disease and vineyard characteristics in the surveyed area. Vines with foliar symptoms of wood decay of kiwifruit were detected in $96 \%$ of vineyards surveyed in 2003, with incidences ranging from 2 to $40 \%$.

Data demonstrated that there was no significant correlation $(P=0.05)$ between incidence and each of the measured parameters except for iron (Table 1). $R^{2}$ values for correlation between disease appearance and soil characteristics such as texture, total nitrogen, available phosphorus, exchangeable potassium, $\mathrm{pH}$, active lime, and organic substance ranged from 0.0004 to 0.0311 ; age of vineyard, pollinators, and nutrient management strategies
Table 2. Mean percentage of annual and cumulated incidence of the disease assessed in four vineyards in which the disease appeared for the first time in 2003

\begin{tabular}{ccc}
\hline & \multicolumn{2}{c}{ Disease incidence (\%) } \\
\cline { 2 - 3 } Year & Annual $^{\mathbf{y}}$ & Cumulative $^{\mathbf{y}}$ \\
\hline 2003 & $6.9 \mathrm{c}^{\mathrm{z}}$ & $6.9 \mathrm{a}$ \\
2004 & $34.6 \mathrm{a}$ & $38.5 \mathrm{~b}$ \\
2005 & $22.5 \mathrm{~b}$ & $48.9 \mathrm{c}$ \\
2006 & $15.5 \mathrm{~b}$ & $56.0 \mathrm{~d}$ \\
\hline
\end{tabular}

${ }^{y}$ For each year, the annual disease incidence was calculated as the number of symptomatic vines over the number of all inspected vines; the cumulated disease incidence was calculated as the number of symptomatic vines plus diseased vines that did not show symptoms in that year over the number of all inspected vines.

${ }^{\mathrm{z}}$ Means followed by the same letter do not differ significantly according to Duncan's multiple range test $(\alpha=0.05)$.

were also not correlated with annual incidence of disease $\left(0.0064<R^{2}<0.0805\right)$. Although the statistical analysis showed that the correlation between iron and disease incidence was significant $(P=0.05)$, the low value of $R^{2}(0.1873)$ suggested that a linear correlation cannot be clearly established.

Results of cluster analysis on vineyards where all parameters were detected (except for available phosphorus) identified a main group of 36 vineyards $(81.8 \%$ of the analyzed vineyards) and 5 groups each consisting of 1,2 , or 3 vineyards characterized by unusually high or low values of at least one parameter (Fig. 2). The percentage of symptomatic vines in the main group ranged from 0 to $40 \%$, so a relationship between the annual disease incidence and vineyard groups was not assessed.

First appearance in vineyards and spread of disease in following years. The mean percentage of annual and cumulative 


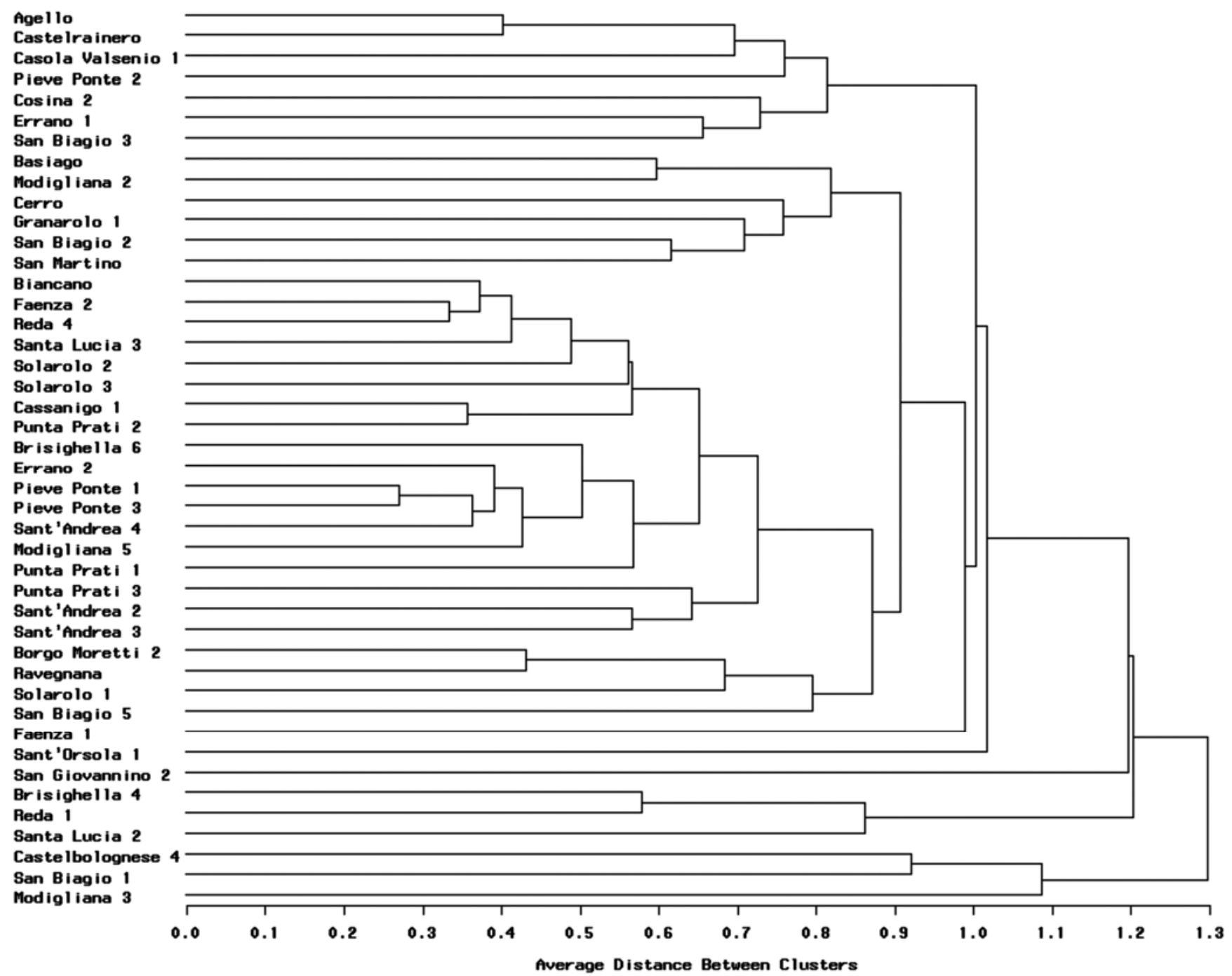

Fig. 2. Dendrogram derived by cluster analysis of similarities between annual incidence of the disease assessed in 2003 and vineyard, soil, and nutrition parameters. Analysis was performed in vineyards in which all given parameters were collected. The average linkage method (SAS system software) was used.

incidence of disease is reported in Table 2. The 4-year survey began in 2003, when symptoms first appeared in vineyards at a mean incidence of $6.9 \%$ (ranging from 3.7 to $10.6 \%$ ). The annual incidence fluctuated widely from year to year, peaking in 2004 at $34.6 \%$ and dropping during 2005 and $2006(P=0.05)$. However, the cumulative incidence steadily increased over the 4 years, reaching $56.0 \%(P=0.05)$, although the annual incidence for the same year was only $15.5 \%$ (Table 2). Vineyards showed a similar trend of disease spread, and the mean percentage of annual and cumulated incidence proved to be statistically different from year to year, except for the annual incidence recorded in 2005 and 2006 ( $P=$ 0.05).

Relationship of temperature or rainfall plus irrigation water with annual disease incidence. Daily average temperatures recorded from June to August in 2003 were much higher than average tem- peratures assessed in 1961 to 2000 (36). Temperatures recorded during August were much higher in 2003 than in the other years (Table 3). Analysis of the relationship between mean annual incidence of symptoms in the surveyed vineyards and monthly average daily temperature for 2003 to 2006 showed strong correlations for the months of June, July, and August, with $R^{2}$ values ranging from 0.82 to 0.85 and standard errors of estimate of $4.46,5.09$, and $4.71 \%$, respectively. The annual incidence of symptoms decreased with increasing June average daily temperatures, ranging from $34.5 \%$ of symptomatic vines at $20^{\circ} \mathrm{C}$ to $6.9 \%$ at $25.5^{\circ} \mathrm{C}$ (Fig. 3A). Regression curves for July and August showed a daily average temperature of 23 to $24^{\circ} \mathrm{C}$ correlated with the maximum expression of disease incidence, which decreased with increasing or decreasing temperature (Fig. 3B and $\mathrm{C}$ ).
Although the monthly rainfall recorded in the June to August period varied throughout the 4 years of inspection, the total amount of rainfall and irrigation water proved to be rather constant for each month, except for August 2005 (Fig. 4A). Therefore, no relationship between annual incidence of disease and rainfall plus irrigation water was found.

Timing of first symptom appearance and consequent disease development on vines within a single vineyard surveyed over four seasons. Data recorded in the 2002 to 2005 survey showed that foliar symptoms began to appear in the vineyard at 29 to 33 DAFB. Although first appearance of the disease was noticed in the second half of the 1990s, visual inspection of disease incidence was carried out for the first time in 2002. External symptoms did not appear consistently on diseased vines each year of inspection. The annual incidence was lower in $2003(44.4 \%)$ and 
Table 3. Daily temperature recorded for lowland and hilly vineyards for the months June to August over the surveyed period

\begin{tabular}{|c|c|c|c|c|c|c|}
\hline \multirow[b]{3}{*}{ Year } & \multicolumn{6}{|c|}{ Temperature $\left({ }^{\circ} \mathbf{C}\right)$} \\
\hline & \multicolumn{3}{|c|}{ Lowland vineyards } & \multicolumn{3}{|c|}{ Hilly vineyard } \\
\hline & June & July & August & June & July & August \\
\hline 2002 & $\mathrm{-}^{\mathrm{y}}$ & - & - & 22.6 & 23.6 & 22.8 \\
\hline 2003 & $25.5^{z}$ & 26.5 & 27.5 & 26.0 & 26.9 & 29.1 \\
\hline 2004 & 19.9 & 23.6 & 23.8 & 21.4 & 24.6 & 24.4 \\
\hline 2005 & 20.6 & 23.1 & 21.6 & 23.2 & 25.8 & 23.5 \\
\hline 2006 & 21.8 & 24.6 & 21.2 & - & - & - \\
\hline
\end{tabular}

y Data not recorded.

${ }^{\mathrm{z}}$ Temperature data were recorded daily at weather stations of ARPA (hilly vineyard) and at Forlì airport (lowland vineyards). For each month, temperature was calculated as the mean of the average temperatures recorded for each day of the month.
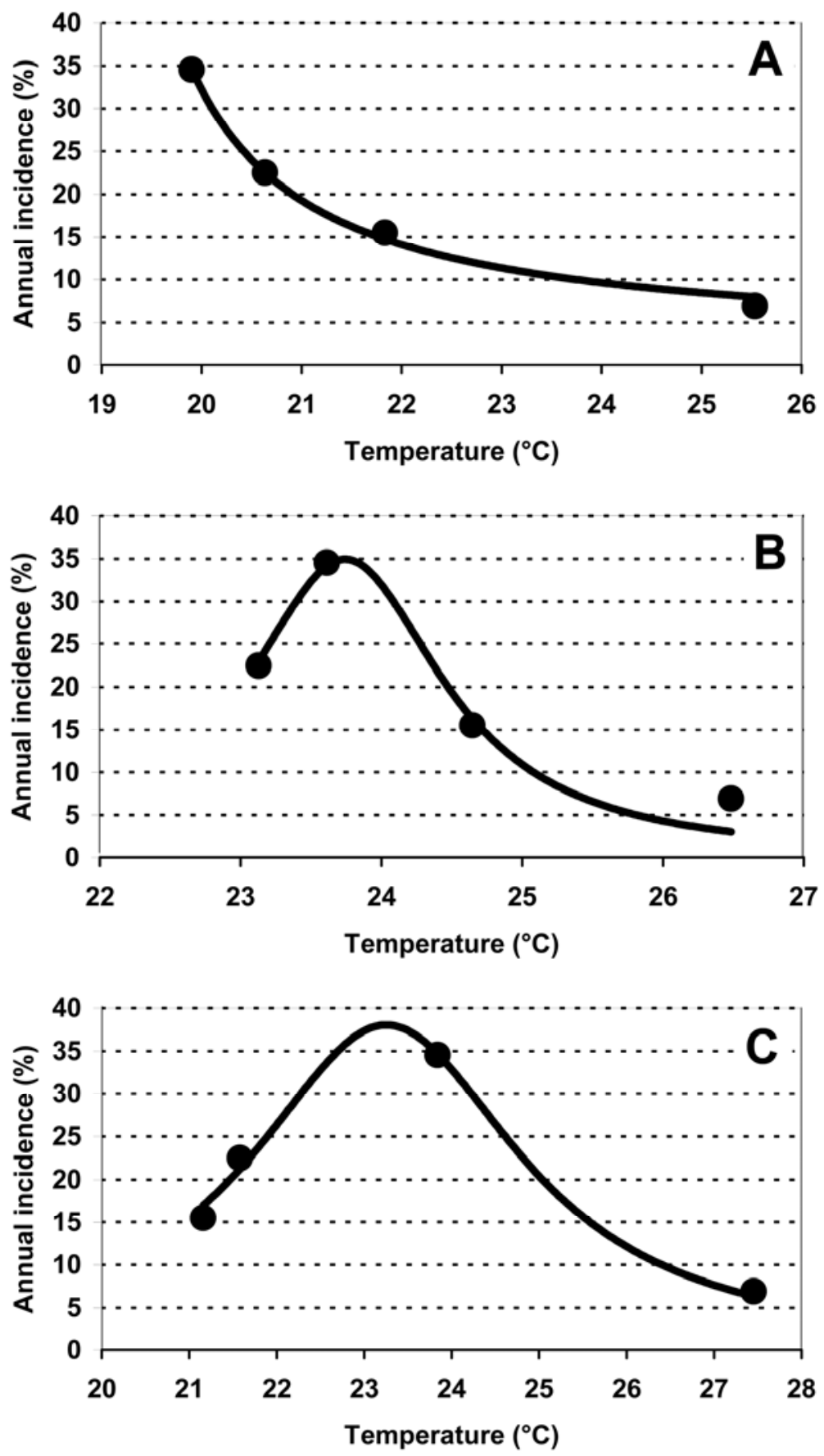

Fig. 3. Curves of correlation between the mean of annual disease incidence and the monthly average daily temperature for A, June, B, July, and C, August. Curves were obtained by equations fitted to the measured data of annual disease incidence and the monthly average daily temperature. higher in 2004 (55.6\%) compared with $2002(51.1 \%)$ and $2005(48.9 \%)$. The cumulative incidence increased over the 4year period, reaching $80 \%$ in 2005 , while the annual incidence in the same year was $48.9 \%$ (Fig. 5).

For each year, the variation in trend of daily average temperatures is more clearly seen from 60 to 95 DAFB, i.e., the month of August which showed low values of average temperatures in 2002 and 2005 and high in 2003 compared with 2004 temperatures (Table 3). The total amount of rainfall and irrigation water was relatively constant for each month of assessment, except for August 2005 (Fig. 4B).

The incidence of symptomatic vines increased over the growing seasons. The increase in symptomatic vines during the 4 years of inspection was uniform until 60 DAFB was reached (Fig. 6A). After this period, during the month of August (about 60 to 90 DAFB), the rate of increase of symptomatic vines varied for each year, as shown by the increase of the standard error calculated for each DAFB (Fig. 6A).

For each time of inspection, the percentage of symptomatic shoots per total shoots of symptomatic vines increased over the 4year survey period, reaching values ranging from 22.3 to $29.9 \%$ in 2004 and 2003 , respectively, at about 95 DAFB. The trend of the percent increase of symptomatic shoots was quite different for each year of inspection as shown by the variability of the standard error calculated for each DAFB (Fig. 6B).

\section{DISCUSSION}

Wood decay of kiwifruit was widespread over the kiwifruit growing areas surveyed. Even in 2003, a particularly warm and dry year (36), when disease incidence was at its lowest level in the 5 years of inspection, nearly all the vineyards surveyed showed symptomatic vines. The disease increased dramatically after the first year of the survey: over the 4 years of inspection, the incidence of diseased vines in vineyards showing symptoms for the first time increased by eightfold.

In 2003, the relationship $\left(R^{2}\right)$ between the percentage of symptomatic vines in 89 vineyards with each parameter measured was never greater than 0.1873 (iron). Iron showed a significant correlation with the annual incidence. Although some vineyards presented a low disease incidence at high levels of iron, most vineyards did not show any correlation, leading to a low value of $R^{2}(0.1873)$. Therefore, the influence of iron on symptomatic expression of the disease may not be excluded, but a linear correlation between annual incidence and iron was not found.

Studies are underway on the relationship between iron and disease. A possible role of iron in mechanisms of wood degradation by $P$. aleophilum associated with the production of reactive oxygen species was 
hypothesized $(11,18)$. However, the relationship between wood pathogenic mechanisms and foliar symptoms is far from being understood.

The results presented in this paper suggest that there was no clear effect on foliar symptoms by vineyard soil characteristics or crop management methods. Foliar symptoms, therefore, possibly correlate with other factors that are discussed below.

Findings from this study provide evidence to support the similarity between esca of grapevine and wood decay of kiwifruit, in addition to the pathogens involved $(9,10,12,29)$. The foliar symptoms associated with wood decay of kiwifruit do not appear consistently every season. Failure of symptoms to appear in a certain year, even though vines are still infected, is a characteristic of both diseases. After 4 years of inspection of vineyards where the disease appeared for the first time, the data showed that annual incidence was about $29 \%$ of cumulated incidence, which may be considered to approximate the real incidence of disease. Hence, incidence of the disease in a given vineyard measured at a single time point is inevitably underestimated. Therefore, the intermittent nature of foliar symptom expression is not a peculiarity of esca or another grapevine trunk disease, Eutypa dieback $(3,14,25,30$,
38,39). It is not known exactly what causes foliar symptom fluctuation from year to year, but in the case of esca, the intermittent appearance of foliar symptoms might be associated with a kind of critical threshold of phytotoxins in the leaves. Such compounds are known to be produced at least by $P$. aleophilum $(1,16$, 25,40).

Each year, foliar symptoms associated with the wood decay of kiwifruit regularly appeared 29 to 33 DAFB, a period of time corresponding to peaks of leaf stomatal conductance and fruit transpiration in kiwifruit as measured by Miller et al. (26) and Montanaro et al. (28). These peaks are
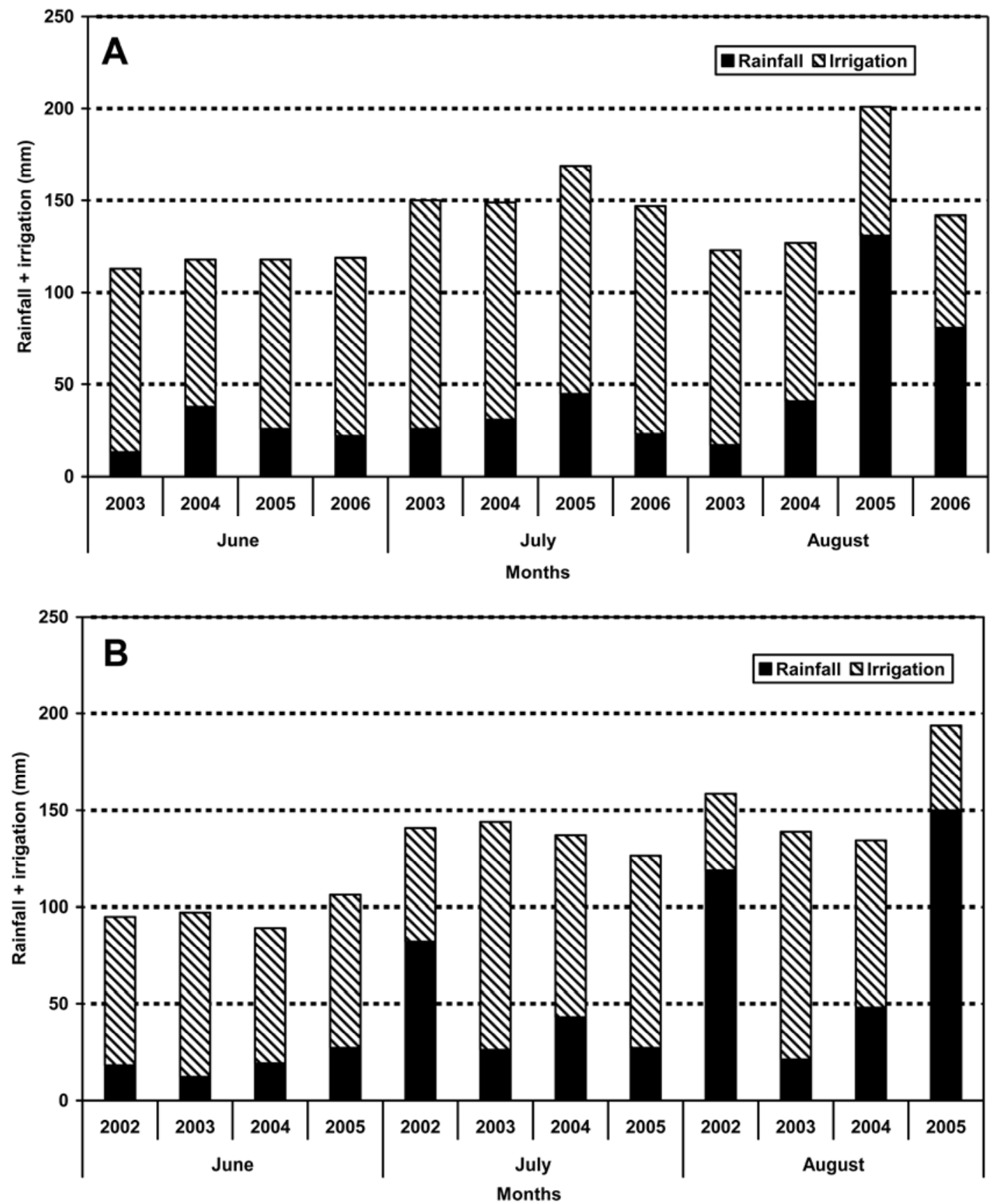

Fig. 4. Monthly total amount of rainfall and irrigation water in $\mathbf{A}$, lowland and $\mathbf{B}$, hilly vineyards. For the 2002 to 2006 period, rainfall was recorded at the National Agro-Meteorological Data Bank of the Central Office of Agro-Ecology (lowland vineyards) and ARPA (hilly vineyard); irrigation data were calculated from the vineyard drip irrigation system equipment. 


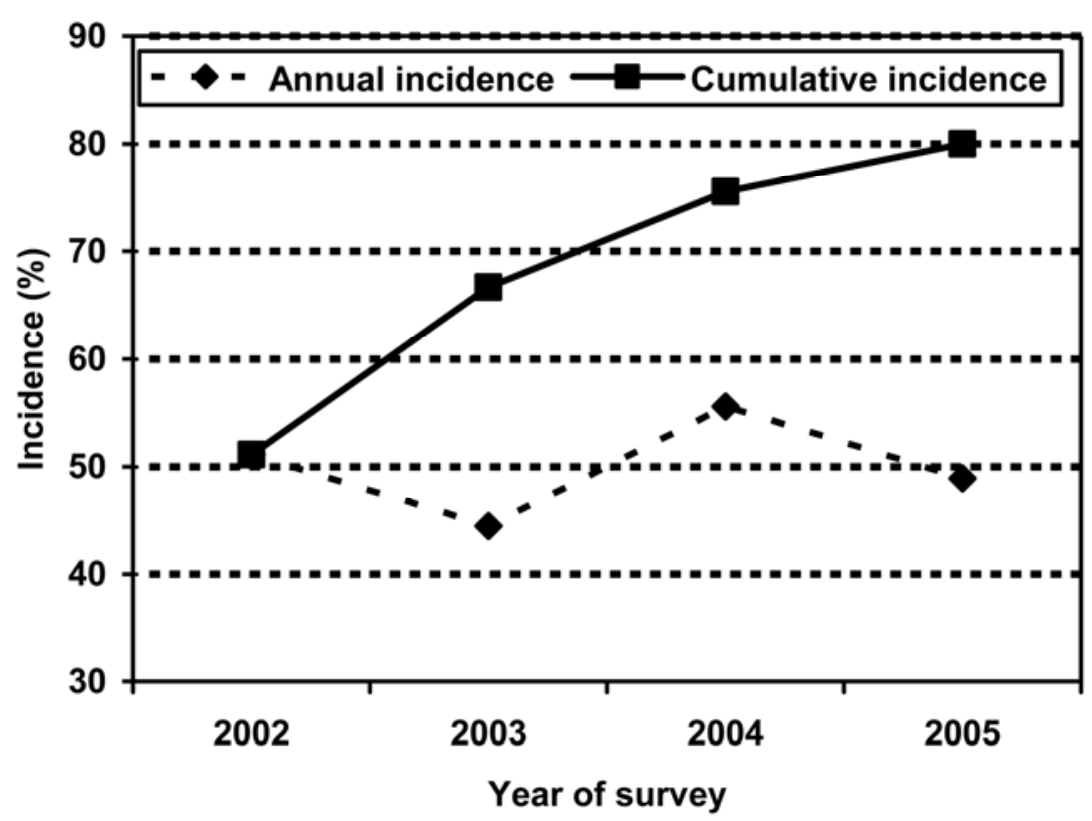

Fig. 5. Percentage of annual and cumulated incidence of disease. The survey was carried out in a vineyard in which the disease was already widespread, with symptoms first noticed during the late 1990s.
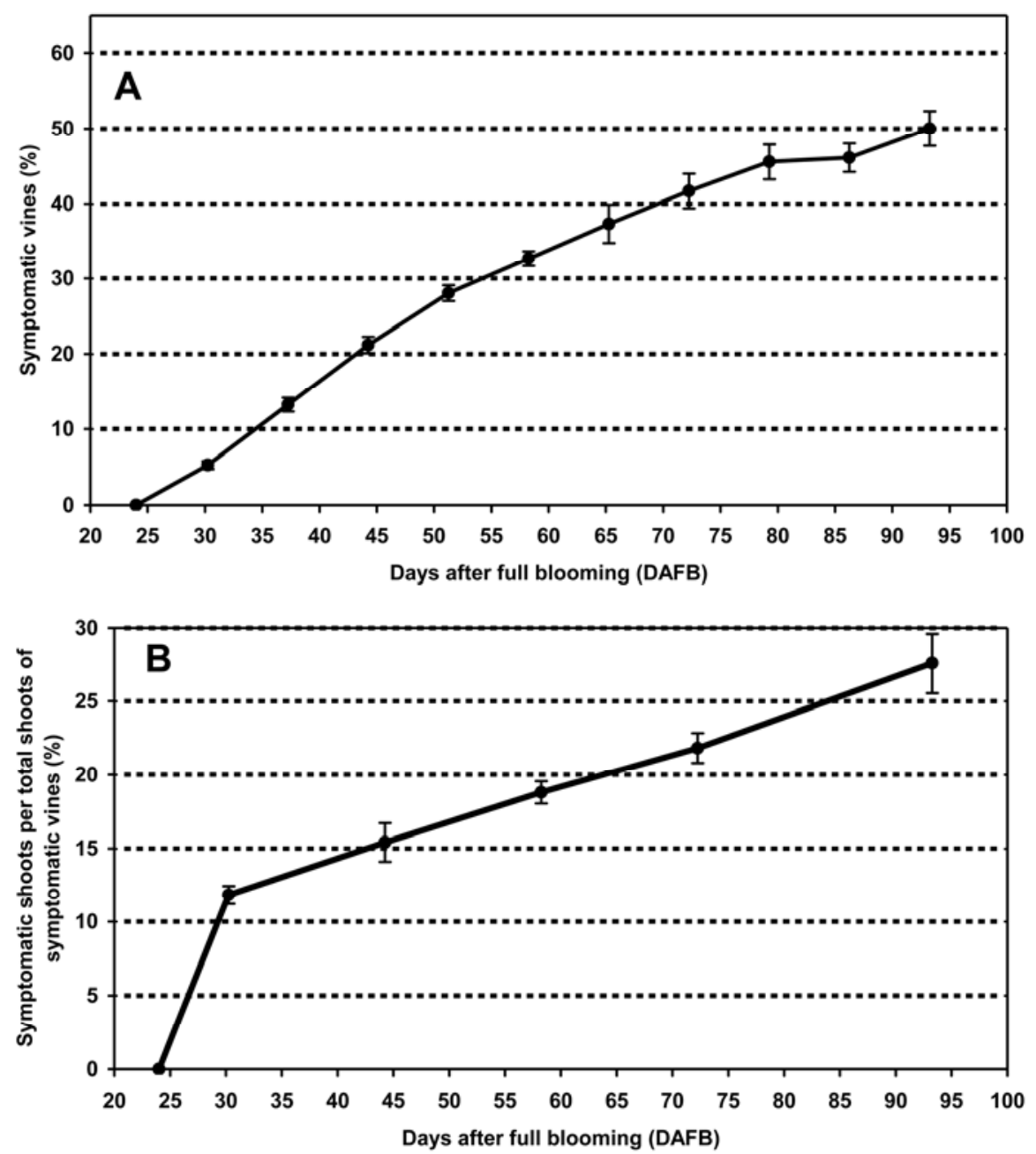

Fig. 6. A, Percentage of symptomatic vines (vines showing foliar symptoms on at least one symptomatic shoot), and $\mathbf{B}$, percentage of symptomatic shoots (number of symptomatic shoots per total number of shoots in symptomatic vines). The vineyard was surveyed from 2002 to 2005 at different intervals after full blooming. Bars indicate standard error of the mean for each time of inspection in the surveyed period. associated with an enhanced rate of plant physiological processes, i.e., transpiration and photosynthesis, as well as with a greater translocation of phytotoxic substances and their accumulation in the leaf.

The rate of translocation is normally regulated by the relationship between plant and environmental factors, especially rainfall and temperature (6). Marchi et al. (25) hypothesized that water availability may have a role in the foliar symptom expression of esca. Kiwifruit is regularly irrigated during the June to August period, in order to satisfy the plant's optimal water requirement and avoid the negative effects of water stress on fruit quality $(23,26)$. Data of rainfall plus irrigation water recorded in the lowland and hilly vineyards showed that monthly amounts of irrigation water were correlated with rainfall, so that the total amount of monthly rainfall plus irrigation water was rather constant for each month over a 5-year period of inspection, except for the assessment in August 2005. In that month, the amount of rainfall plus irrigation water was higher than normally recorded in other years because of water runoff due to heavy, concentrated rainfall. In any case, variations in the annual incidence of the disease were not correlated with plant water availability (rainfall plus irrigation water).

Temperature can play a role on the plant-infection complex during the growing season. Our results demonstrated that the annual incidence of disease decreased significantly with increasing daily average temperatures in June. The correlation between June temperatures and percentage of symptomatic vines cannot be explained as a simple scheme of cause and effect, especially if it is considered that every year the disease regularly appeared at the end of June and the increase in symptomatic vines was rather uniform until the beginning of August. It therefore seems reasonable to assume that the increase in June daily average temperatures up to $25^{\circ} \mathrm{C}$ affected physiological processes such as transpiration, and thus indirectly affected the annual incidence of disease.

July temperatures varied little among the years surveyed $\left(3.5^{\circ} \mathrm{C}\right.$ compared with 6 to $6.5^{\circ} \mathrm{C}$ for June and August). Therefore, additional years of observation are needed to better understand the correlation between the annual incidence of wood decay of kiwifruit and the July daily average temperatures. However, the data recorded in the 4 years of inspection showed that maximum annual foliar symptom expression $(34.5 \%)$ was associated with a July daily average temperature of 23 to $24^{\circ} \mathrm{C}$.

A correlation between a daily average temperature of 23 to $24^{\circ} \mathrm{C}$ and the maximum annual disease was also found for August, when temperatures interacted more directly with foliar symptom expression. The relationship between August daily temperatures and annual disease 
incidence could be explained in terms of the physiological processes occurring nearly 60 days after full blooming, corresponding to the beginning of August in the Northern Hemisphere. At 60 days after full blooming, there is a permanent dysfunction of the fruit vascular system of kiwifruit, and fruit transpiration decreases substantially; these physiological processes were influenced by environmental conditions, particularly temperature $(7,28)$. At the same time, the nutritional content of the leaves (i.e., nitrogen, potassium, sulfur, and boron) is at maximum (37). Maybe in that period more than at any other time during the growing season, substances including phytotoxic compounds associated with foliar symptoms concentrate in the leaf, favoring foliar symptom expression $(1,16,40)$.

On the whole, a correlation between plant phenology, temperature, foliar disease symptom appearance and incidence was clearly noticed. The rate of annual incidence of wood decay of kiwifruit appeared to be correlated with June, July, and August temperatures, and the appearance and spread of the disease was dependent on complex physiological processes involved in plant growth.

Although further studies are needed, results reported in this paper, particularly the relationship between the disease and plant physiological stages, form the basis for further studies to estimate and predict the rate of incidence of wood decay of kiwifruit in the vineyard, whose fruit yield is strictly correlated with the severity of foliar symptoms on the plant.

\section{ACKNOWLEDGMENTS}

The work was partially supported by the Centro Ricerche Produzioni Vegetali (CRPV). We thank G. Surico and L. Mugnai, Dipartimento di Biotecnologie Agrarie, Università degli Studi di Firenze, Italy, and M. Manning, HortResearch New Zealand, for critically reviewing the manuscript. We also thank the technicians of Coop Intesa and G. Spada for helping in collecting the vineyard data.

\section{LITERATURE CITED}

1. Abou-Mansour, E., Couché, E., and Tabacchi, R. 2004. Do fungal naphthalenones have a role in the development of esca symptoms? Phytopathol. Mediterr. 43(1):75-82.

2. Brook, P. J. 1986. Diseases of kiwifruit. Pages 420-428 in: Kiwifruit: Science and Management. I. J. Warrington and G. C. Weston, eds. Ray Richards Publisher, Auckland, New Zealand.

3. Calzarano, F., Cichelli, A., and Odoardi, M. 2001. Preliminary evaluation of variations in composition induced by esca on cv. Trebbiano d'Abruzzo grapes and wines. Phytopathol. Mediterr. 40:443-448.

4. Calzarano, F., Spada, G., Montuschi, C., and Di Marco, S. 1999. Una forma di deperimento lignicolo colpisce i fruttetti italiani di Actinidia deliciosa. Inform. Fitopatol. 49:12-15.
5. Costa, G. 1999. Kiwifruit orchard management: New developments. Acta Hortic. (ISHS) 498:111-126.

6. Davison, R. M. 1999. The physiology of the kiwifruit vine. Pages 127-154 in: Kiwifruit Science and Management. I. J. Warrington and G. C. Weston, eds. Ray Richards Publisher, Auckland, New Zealand.

7. Dichio, B., Rumorini, A., and Lang, A. 2003. Developmental changes in xylem functionality in kiwifruit fruit: Implications from fruit calcium accumulations. Acta Hortic. (ISHS) 610:191-195.

8. Di Marco, S., Calzarano, F., Gams, W., and Cesari, A. 2000. A new wood decay of kiwifruit in Italy. N.Z. J. Crop Hortic. 28:69-73.

9. Di Marco, S., Calzarano, F., Osti, F., and Mazzullo, A. 2004. Pathogenicity of fungi associated with a decay of kiwifruit. Aust. Plant Pathol. 33(3):337-342.

10. Di Marco, S., and Osti, F. 2006. Carie dell'actinidia: Nuove acquisizioni epidemiologiche ed interventi di capitozzatura. Atti Giornate Fitopatol. 2:141-142.

11. Di Marco, S., Osti, F., Mazzullo, A., and Cesari, A. 2001. How iron could be involved in esca fungi development. Phytopathol. Mediterr. 40:449-452.

12. Di Marco, S., Osti, F., and Spada, G. 2002. La carie dell'actinidia. Frutticoltura 44:59-63.

13. Di Marco, S., Osti, F., and Spada, G. 2003. The wood decay of kiwifruit and first control measures. Acta Hortic. (ISHS) 610:291-294.

14. Edwards, J., Marchi, G., and Pascoe, I. G. 2001. Young esca in Australia. Phytopathol. Mediterr. 40:303-310.

15. Elena, K., and Paplomatas, E. J. 2002. First report of Fomitiporia punctata infecting kiwifruit. Plant Dis. 86:1176.

16. Evidente, A., Sparapano, L., Andolfi, A., and Bruno, G. 2000. Two naphthalenone pentaketides from liquid cultures of Phaeoacremonium aleophilum a fungus associated with esca of grapevine. Phytopathol. Mediterr. 39(1): 162-168.

17. Fischer, M. 2002. A new wood-decaying basidiomycete species associated with esca of grapevine: Fomitiporia mediterranea (Hymenochaetales). Mycol. Prog. 1:315-324.

18. Goodell, B., Jellison, J., Liu, J., Daniel, G., Paszczynski, A., Fekete, F., Krishnamurthy, S., Jun, L., and Xu, G. 1997. Low molecular weight chelators and phenolic compounds isolated from wood decay fungi and their role in the fungal biodegradation of wood. J. Biotechnol. 53:133-162.

19. Hennion, G., Baudry, A., Lecomte, P., Durpaire, M. P., Mouyon, M., Tailleur, J. L., and Larignon, P. 2001. Le depérissement du kiwi: le bois malade de l'esca. Infos-Ctifl 176:25-27.

20. Hennion, B., Lecomte, P., Larignon, P., Baudry, A., Durpaire, M. P., Mouillon, M., Tailleur, J. L., and Dupuy, O. 2003. First observations of a wood decay (esca-like disease) on kiwifruit in France. Acta Hortic. (ISHS) 610:409-413.

21. Horticultural and Tropical Product Division, Foreign Agricultural Service, USDA. 2003. Kiwifruit Situation and Outlook, Circular article. Online resources.

22. ISTAT. 2006. Dati congiunturali sull'agricoltura e zootecnia database - dati congiunturali sulle coltivazioni, anno 2005. Retrieved Oct. 6, 2006.

23. Judd, M. J., and McAneney, K. J. 1987. Economic analysis of kiwifruit irrigation in a hu- mid climate. Adv. Irrigation 4:307-330.

24. Manning, M., Meier, X., and Olsen, T. L. 2004. Etiology of vine decay in kiwifruit cv. "Hayward" in New Zealand. Tavola rotonda "Il punto della situazione sul deperimento del legno del kiwi. Roma, 12 dicembre 2004.

25. Marchi, G., Peduto, F., Mugnai, L., Di Marco, S., Calzarano, F., and Surico, G. 2006. Some observations on the relationship on manifest and hidden esca to rainfall. Phytopathol. Mediterr. 45:117-126.

26. Miller, S. A., Smith, G. S., Boldingh, H. L., and Johansson, A. 1998. Effects of water stress on fruit quality attributes of kiwifruit. Ann. Bot.-London 81:73-81.

27. Ministero dell'Agricoltura e delle Foreste. 1992. Decreto Ministeriale 79/92, 11 maggio 1992 Approvazione dei "Metodi ufficiali di analisi chimica del suolo". Gazzetta Ufficiale della Repubblica Italiana n. 121/92 del 15-051992, Supplemento Ordinario n. 79.

28. Montanaro, G., Dichio, B., Xiloyannis, C., and Celano, G. 2006. Light influences transpiration and calcium accumulation in fruit of kiwifruit plants (Actinidia deliciosa var. deliciosa) Plant Sci. 170:520-527.

29. Mugnai, L., Graniti, A., and Surico, G. 1999. Esca (black measles) and brown woodstreaking: Two old and elusive diseases of grapevines. Plant Dis. 83:404-418.

30. Mugnai, L., Imbriani, R., and Surico, G. 1996. Indagine sulla diffusione e gravità del "mal dell'esca" in alcuni vigneti della Toscana. Inform. Fitopatol. 46(6):50-56.

31. Nipoti, P., Prodi, A., Sandalo, S., and Credi, R. 2004. Further studies on the main fungi associated with elephantiasis of kiwifruit. J. Plant Pathol. 86(4):327.

32. Nipoti, P., Sandalo, S., Prodi, A., Credi, R., Spada, G., and Graziani, S. 2003. An unusual wood decay of kiwifruit in Italy. Acta Hortic. (ISHS) 610:253-259.

33. Patterson, A. 2006. New Zealand Kiwifruit Annual. GAIN Report NZ6002, Foreign Agicultural Service, USDA. Retrieved Jan. 20, 2006, 1-5.

34. Prodi, A., Gonzalez, I., Sandalo, S., Terlizzi, F., and Nipoti, P. 2003. Elephantiasis of kiwifruit: Biological and molecular characterization of some disease-associated fungi. J. Plant Pathol. 85(4):313.

35. Salinger, M. J., and Kenny, G. J. 1995. Climate and kiwifruit cv. "Hayward" 2. Regions in New Zealand suited for production. N.Z. J. Crop Hortic. 23:173-184.

36. Schär, C., Vidale, P. L., Lüthi, D., Frei, C., Häberli, C., Liniger, M. A., and Appenzeller, C. 2004. The role of increasing variability in European summer heatwaves. Nature 427:332336.

37. Smith, G. S., Clark, C. J., and Henderson, H. V. 1987. Seasonal accumulation of mineral nutrients by kiwifruit. New Phytol. 106:81-100.

38. Sosnowski, M., Shtienberg, D., Creaser, M., Wicks, T., Lardner, R., and Scott, E. 2005. Unlocking the secrets of seasonal variation in eutypa dieback symptoms. Aust. N.Z. Grapegrower Winemaker 497a: 7-12.

39. Surico, G., Marchi, G., Braccini, P., and Mugnai, L. 2000. Epidemiology of esca in some vineyards in Tuscany (Italy). Phytopathol Mediterr. 39(1):190-205.

40. Tabacchi, R., Fkyerat, A., Poliart, C., and Dubin, G. M. 2000. Phytotoxins from fungi of esca of grapevine. Phytopathol. Mediterr. 39(1):156-161. 